\title{
低凝固点水溶液による水平水層の温度・漶度複合融解*
}

\author{
菅原征洋**，稲真英男***，西村 斉*****
The Temperature-concentration Combined Melting of a Horizontal Ice Layer by an Aqua-solvent with a Low Solidification Temperature \\ Masahiro SUGAWARA, Hideo INABA, and Hitoshi NISHIMURA

\begin{abstract}
This paper is concernd with the melting of a horizontal ice layer from above by an aqua-solvent with a low solidification point. The solutes used in this experiment are Calcium Chloride and Urea. The upper surface of the melt layer is heated by radiative energy. The ice layer located under the melt layer of the aqua-solvent melts greatly by a combined effect of both thermal energy and chemical reaction, and the typical temperature distribution in both the melt layer and the ice layer is examined. The relation between the melt amount of the ice layer per unit temperature gradient and the mean concentration in the melt layer of aqua-solvent was obtained.
\end{abstract}

Key Words: Thermal Engineering, Horizontal Ice Layer, Melting, Aqua-Solvent, Calcium Chloride, Urea

1. ま か か

雪層や氷層を塭化カルシウム水溶液などのような低 凝固点水溶液で融解させる場合，たとえ氷塊と水溶液

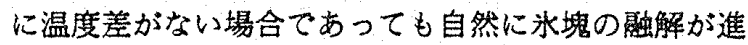
行することはよく知られていでは交熱エネルギを加え ることなしで迅速に雪膚や氷塊を融解させるには極め て有効な方法といってよい，しかしながら水溶液を含 む融解系が平衡状態に達すると，そのままでは氷塊の 融解がもはや期待できないことが考えられるなど，な お解決すべき問題もあることも事実である。

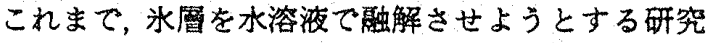
は極めて少ないが, Griffin ${ }^{(2)}$ は塩水中の水圈融解に関 する理論的研究を行って, 固波界面近傍の温度, 灌度 および速度分布について検討しているが，この中て， 固液界面の熱平衡式に対しては純水中の氷盗融解速度 式にかかわる Neumannの用いた条件 ${ }^{(3)}$ をえて適用 している.最近 Sammakia ら(4)は塩水中に站かれた垂 直水板の融解に関する実験を行って，虽解量から算出

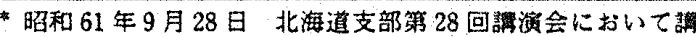
演，原稀受付，昭和 60 年 12 月 20 日。

** 正只, 秋田大学轨山学部（010 秋田市手形学園町 101 ).

****正員，北見工栄大学（8090 北見市公園町 165 畄地）。

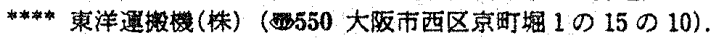

したヌセルト数は通常の自然対流熱伝達と比較してか なり高い徝を示すという特徽的な結果を報告している が,これについての明確な説明がなされておらず，こ の種の研究についてはなお解決すべき問題が多いとい える。

本䂙究は塩化力ルシウム水溶波や尿素水溶液を熱工 ネルギて加熱させた状態，すなわち前述した触解系の 平衡状態の到荛を澼ける条件を設定して水平水曆を融 解させた場合を検討したものですり，温度と洤度の相

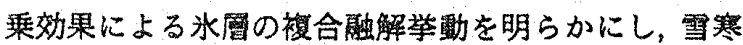

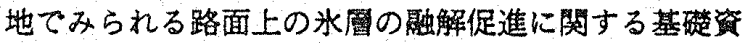
料を得ようとしたものである。

\section{2. 实験结置および方法}

実験装置の概要を图 1 に示す。これ虫氷糜試料の生 成から水層の融解実験まで一贯してできる装置であ

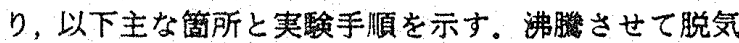
した蒸留水を $0^{\circ} \mathrm{C}$ 付近まて冷却し，これを厚さ $7 \mathrm{~mm}$ のアクリル板て作製されている内容䅡 $100 \times 100 \times 150$ $\mathrm{mm}^{3}$ の容器の所定の浨さまて入れる。

次に,この容器の下にあって，しかもこれと一体に なっている冷却部に冷凍機によって冷却された一定温 度のエチレン・グリコール水溶液を循環させて気泡の 
含まない透明な氷試料をまずつくる。このためには， 米試料をつくるのに約 3 日間活どの長い時間をかけ， 凄結速度を非常に幄くして氷試料をつくることが大切 である.その後，こうして得られた氷層内の温度分布 を一様に $0^{\circ} \mathrm{C}$ 付近の值に設定する。

次に，所定の質量灌度 wt\%（以後，湄度と略記し， 記号 Cで示す）にした氷溶液を初期の水層温度と同じ $0^{\circ} \mathrm{C}$ の值にした後, 水層上部にこれを注入し, 水溶液 層军さが $20 \mathrm{~mm}$ になるようにする。そして，この装置 の上方に厚さ $1 \mathrm{~mm}$ のアルミニウム板で作製した円 筒内に $250 \mathrm{~W}$ の赤外線電球を取付け，これによって 液層上面を加熱する方法をとった。この場合，先に報 告(s)したように, 液層内の温度分有が伝導伝熱による 場合はほほ直線になることを注意して赤外線電球加熱 によって液層上面を加熱するのである。この場合，こ のふく射エネルギに比較的波長の短いエネルギ，すな わち，水や水溶液に対して吸収係数 ${ }^{(6)(7)}$ が小さい值の エホルギも若干含まれ，このため液層上面の非常に薄 い層では阅線温度分布からはずれる部分が存在するの で、融解挙動を検討するときに用いる液層内の見かけ の温度こう配を推定する際には，図 1 に示すごとく， 液層上面から若干下に位置している熱電対で上面近傍 の温度 $T_{1}$ を測定するようにしてある。

氷層は時間の経過に伴って次第に競解していくがこ のときの液層および承層の温度変化は， $\phi 0.1 \mathrm{~mm}$ の 銅・コンスタンタン熱電対を細いステンレス管に通し たプローブを図1のような配列で水平に設定して打点 記録計とペンレコーダによって测定した。

一次元的な融解を行わせるように厚さ $1 \mathrm{~mm} の ア$ クリル板で作製した角型筒で二重に液層部を図 1 のご とく補償するようにし，さらに厚さ50 mmの断熱材 (スタイロフォーム) て周囲を覆った。

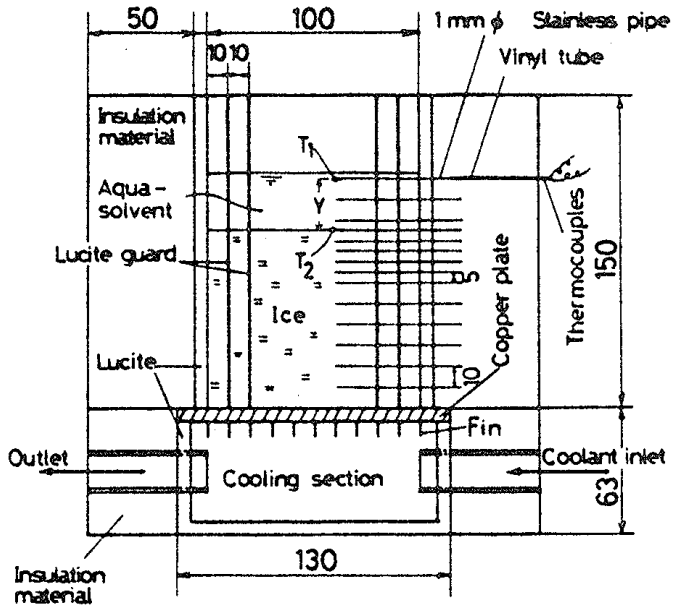

図 1 実験装置概要図
融解單の測定は, 水層の融解進行豆より推定した。 図 2 に, 溜度 0 wt \%すなわち純水による融解の場合 のペンンコーダに記録された界面付近に位置している プロープ熱起電力 $E \mu \mathrm{V}$ と時間 $t \min$ の関係を示し たものである。図中，矢印の位置が融解界面位置であ ることが明確にわかる。この場合, 液尿すなわち融解 嘪の温度おょび浪度場を乱すことなく融解量を測定す る配虑が必要である。

融解中のある時刻における液周すなわち融解層内の 同所的な濃度分有については，所定の深さから針の長

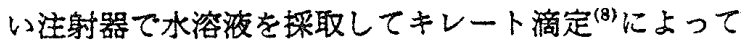
濃度を測定した。

\section{3. 実釾結果および考察}

まず塩化カルシウム（Calcium Chloride, $\mathrm{CaCl}_{2}$ ) 水 溶液に上る氷層の融解について述べる。図 3 は初期筫 度 $C_{i n} \mathrm{wt} \%$ を変化させた場合の融解量（固液界面位置 の変化てあり，一次元的水層厚さの变化 $S \mathrm{~mm}$ で示 してある）と時間 $t \min に$ 関する実測結果を示したも

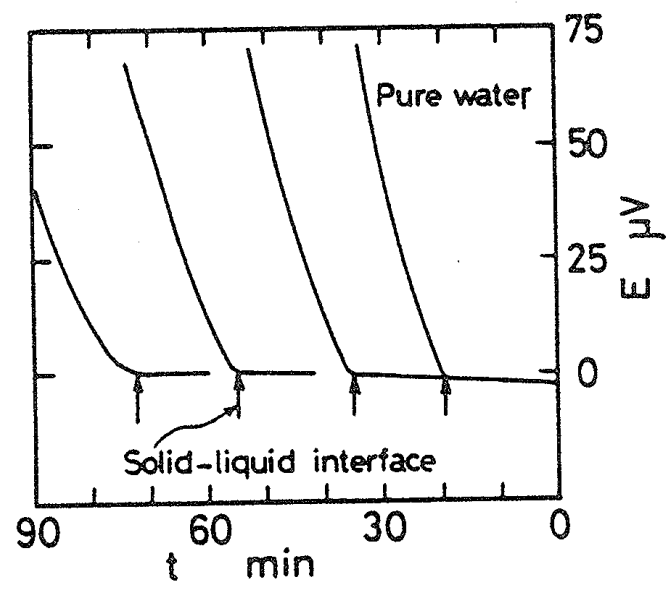

図 2 固液界面位置の測定

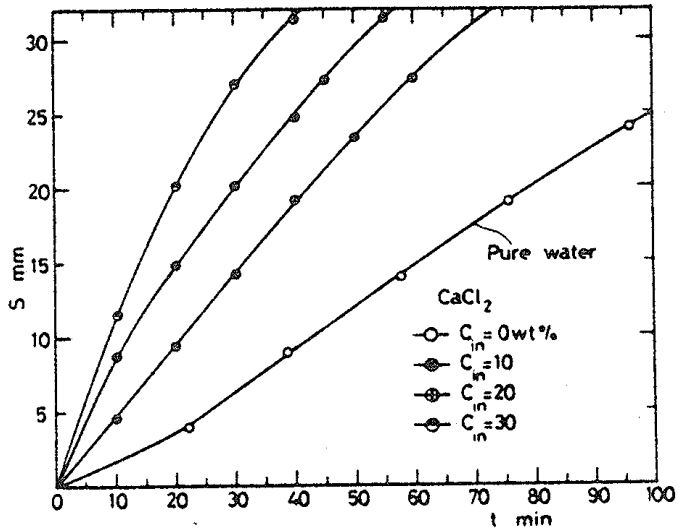

図 3 融解旺の時間的変化（塩化カルシウム） 
のである。なお図中， $C_{i n}=0 \mathrm{wt} \%$ は初期灌度が管すな わち純水による融解の場合であり，これらの加熟条件 は赤外線加熱による等熱流束の場合である。また図 3 中の各種の条件に対する融解液層内ちよび氷層内の温

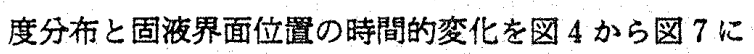
示した. ただし，縦軸は上方からの距㒕 $y \mathrm{~mm}$ ，横軸は 温度 $T^{\circ} \mathrm{C}$ でる。

結果的には，加熱条件が同じであるにもかかわらず，

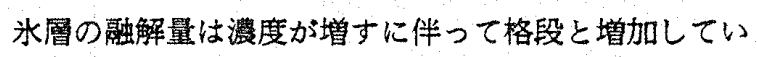
ることがわかる。

図 4 は水溶液の涶度が0 wt \%すなわち純水による 融解の場合の時間的な温度変化である，融解液圈内の 温度分布はほ涩淔線であり，各時間の温度分布を比較 するとそれぞれの温度こう配は類似していることか

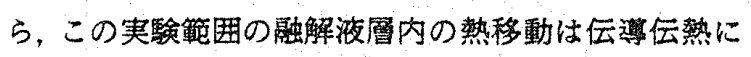
よって行われ，等熱流束加熱下ての融解举動であるこ とを示している。当然のことながら固液界面温度は $0^{\circ} \mathrm{C}$ であって, 氷層内の温度も一様にほほ $0^{\circ} \mathrm{C} に$ 保た れていることがわかる。

図 5 は塩化カルシウム水溶液の初期灌度が $10 \mathrm{wt} \%$ の場合である。これを見ると虽解液層内の温度分布は 前述の純水による融解の場合と異なり，曲線状になっ

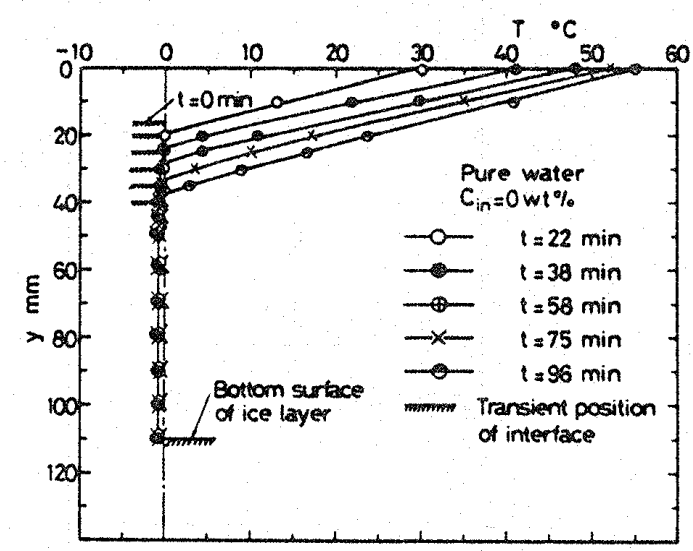

図 4 温度分布 $\left(\mathrm{CaCl}_{2}\right.$ 瀿度 $0 \mathrm{wt} \%$ ，純水）

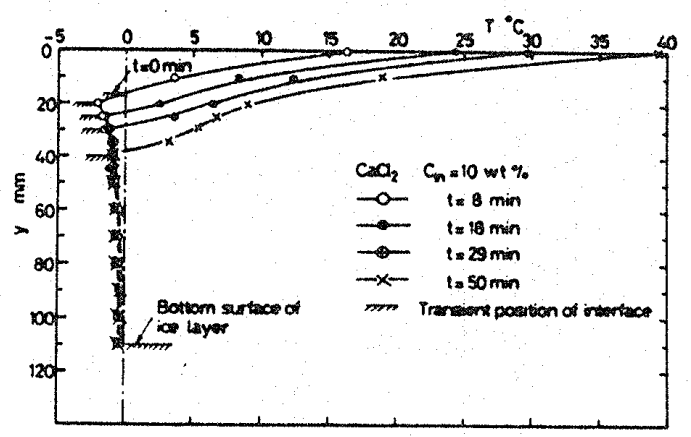

図 5 温度分布 $\left(\mathrm{CaCl}_{2}\right.$ 㩐度 $\left.10 \mathrm{wt} \%\right)$

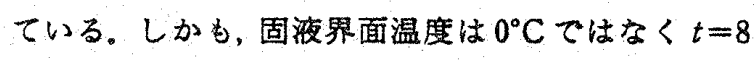
$\min て は-2^{\circ} \mathrm{C}$ 以下にまて路下していて,これに伴っ て氷翼内心温度こう配が生じている。このような傾向 は図 $6\left(C_{i n}=20 \mathrm{wt} \%\right)$, 図 $7\left(C_{i n}=30 \mathrm{wt} \%\right.$ て界面温

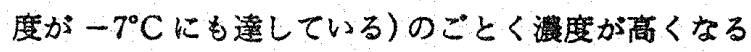
に伴って顕萻になっている。

触解㬝内の温度分布がこの様に曲線状になる原因に ついては, 今のところ明確に説明することは難しいが 次のように考えられる。すなわち，図4のごとく純水 による融解の場合には，畆層内に最大密度をもつ $4^{\circ} \mathrm{C}$ の部分が存在して, $0^{\circ} \mathrm{C}$ (固液界面温度) と $4^{\circ} \mathrm{C}$ 距離

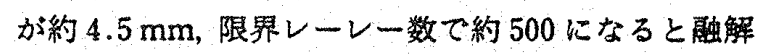
液層内に自然対流が生ずる(5)のであるが，しかし，図 4の結果は限界レーレ一数以下の条件下のものである ので, 本研究の実験範囲内では融解液展内には自然対

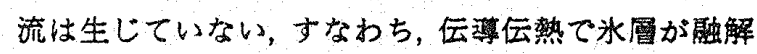
していることが明らかである。一方，水溶液による触 解の場合には固液界面近傍て氷筧の融解に伴って灌度 汴散や混合が生じ液着内の温度場を乱すから，温度分 布が曲線状になったことが考えられる。例えに゙塩水中

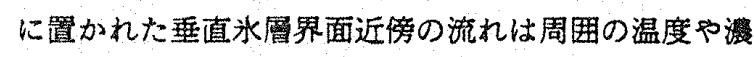
度によって䙓嚾な流れが生ずることが報告されてお $\eta^{(4)}$, 本研究のような水平水層の場合にも，これと類 似した举動が生じているものと思える。

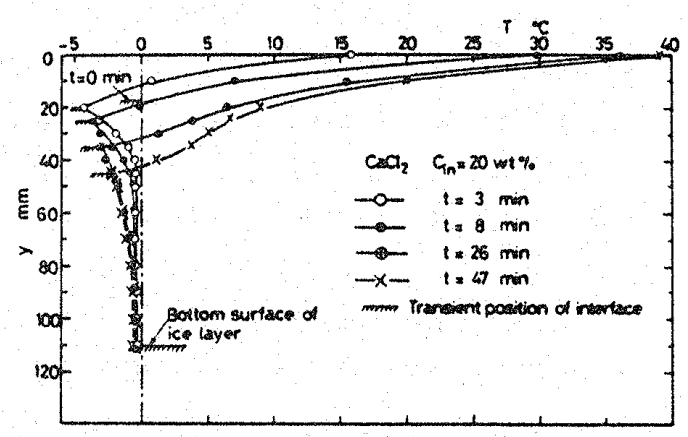

図 6 温度分布 $\left(\mathrm{CaCl}_{2}\right.$ 惯度 $\left.20 \mathrm{wt} \%\right)$

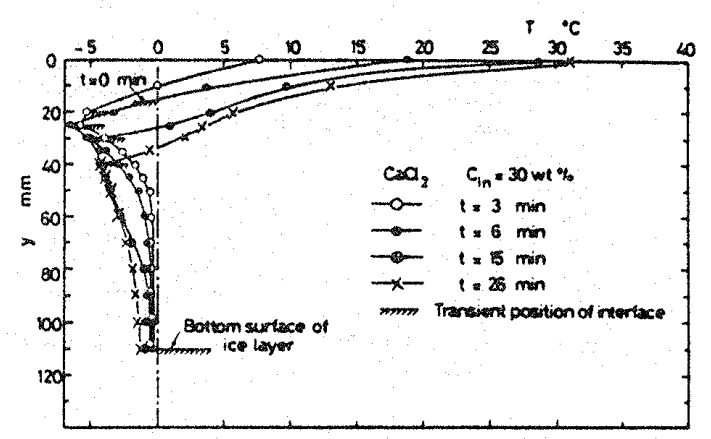

图 7 温度分布 $\left(\mathrm{CaCl}_{2}\right.$ 漫度 $\left.30 \mathrm{wt} \%\right)$ 
また, 固液貥面温度の降下に伴って承畨内に温度こ

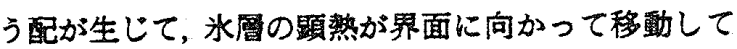
いることがわかる。これは，氷層の温度がたとえ負の 領域であっても承層の融解に奇与するものであるとい う與味ある尌実を示してちり，従来のNeumann問題 では見られなかった特徽的な融解挙動であるといえ る。また，従来の Neumann問題では禹解条件に成係 せず固液界面温度を一定として扱うが，本研究のごと き融解問題では，これまでの赛駼結果からもわかるよ うに，水溶液の種類や莀度はもとより，融解条件すな わち液相および固相の温度場によっても固液界面温度 が変化する融解举動が得られることも考えられる。

こうした傾向に奶し尿素水溶液による融解の場合 は, 塭化カルシウム水溶液の場合と比較して, 融解量 の隇少や固液界面温度が高いなどの相違はあるが, 源 度変化による融解液層内の温度分布は図 8 の $C_{i n}=30$ $w t \% の$ 測定例加ら認められるごとく図 4 に示されて いる純水の温度分布のような直線状に近い挙動を示す という結果が得られた。

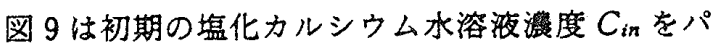
ラメータにとり，融解液圆内の濃度分布を示したもの である。なお，図中の点は実測值であり，実線は氷層の 融解量を水に算し，これを初期謴度の水溶液に加え ることにより求めた平均餐度 $C_{m}$ であって参考のため 示した。これによると， $C_{\text {in }}=30 \mathrm{wt} \%$ の場合は多少溊 度こう配はあるものの全体的に潩度こう配は小さく， 融解層内の淟度分布は融解㻎加ら求めた平均㗳度 $C_{m}$ とあまり差がないことがわかる。また，界面近傍の溲 度も周囲の洎度とあまり差がないことから，界面のご く薄い層で急激な䀶度こう配をもつという Nernst ${ }^{(9)}$ の説の瀿度分布モデルに近いことがわかる。

図 10 は, 横軸に平均戧度 $C_{m} \mathrm{wt} \%$ と縦軸に融解量 $M \mathrm{~kg} /\left(\mathrm{mh}^{\circ} \mathrm{C}\right)$ をとり, 両者の関係を実測值により示 したものである。ただし，hは時間hourの略記であ り，また颈度は図 9 で述べたように氷層の融解量から

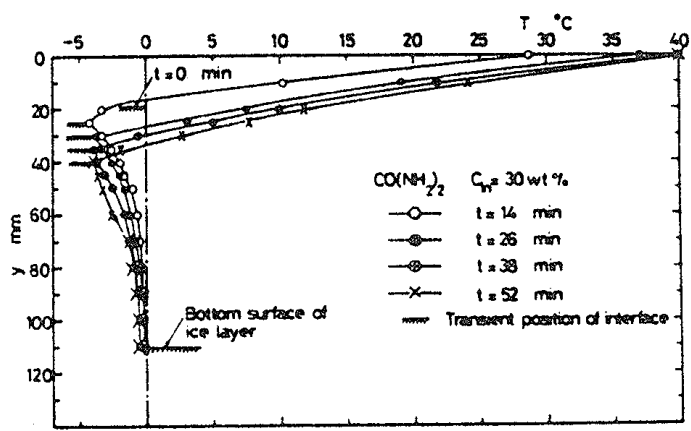

図 8 温度分布 $\left[\mathrm{CO}\left(\mathrm{NH}_{2}\right)_{2}\right.$ 泳度 $\left.30 \mathrm{wt} \%\right]$
求めた平均濒度であって，約 $4 \mathrm{wt} \%$ から 30 wt \%の 䈯囲内のものであり，融解量 $M$ は次の定義によるも のである.

$$
M=\rho \frac{d S}{d t} /\left(\frac{T_{1}-T_{2}}{Y}\right)
$$

ただし， $\rho$ は氷の密度 $\mathrm{kg} / \mathrm{m}^{3}, T_{1}$ 住融解液筧上面近傍 温度 $\mathrm{K}$ であり，約 $280 \mathrm{~K}\left(7^{\circ} \mathrm{C}\right)$ 加ら $313 \mathrm{~K}\left(40^{\circ} \mathrm{C}\right)$

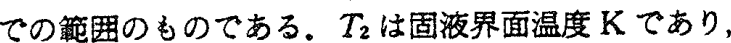
$Y$ 㹥温 $T_{1}$ と $T_{2}$ との距離である。 $M$ は单位温度こ う配あたりの融解量とみなせるが，ただし，氷愿内か ら固液界面に向かう熱县は全融解熱量と比較してこの 場合小さいためこの計算では考虑していない。

図中の一点鎖線は浱度 $0 \mathrm{wt} \%$ すなわち純水による 融解の綰果であり， $M=0.0065$ の值を持っていて， たとえ温度差が增加しても温度こう配が一定であれば 融解量 $M$ の傎は一定の值を持つことがわかる。しか し，水溶液に上る融解の場合は純水による融解の場合 と比較して格段と融解量が增加していることがわか る.

図 10 中の笑線は両対数グラフで実測結果を直線で 近似したものであり，次のような式で表示してある。

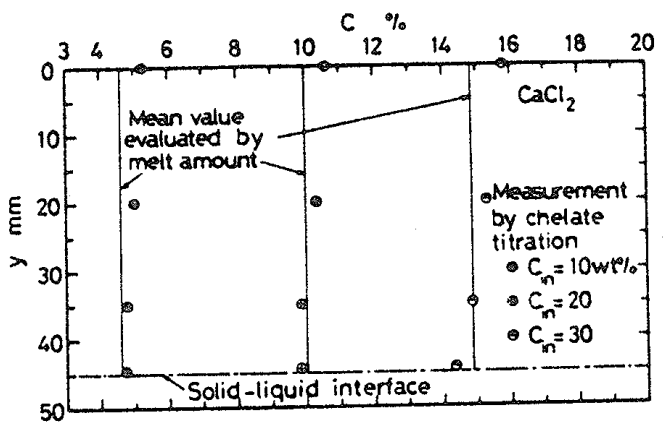

図 9 瀷度分布（塭化カルシウム）

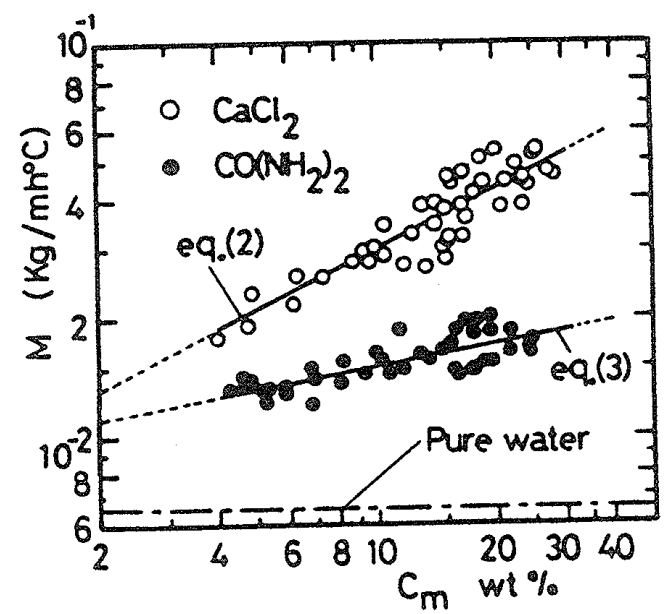

図 10 平均壊度 $C_{m}$ に対する融解量 $M$ 
ただし，Mは kg/ $\left(\mathrm{mh}^{\circ} \mathrm{C}\right), C_{m}$ はwt\%の单位をも

3 .

塩化カルシウム水溶液の場合

$$
M=0.0094 \times C_{m}^{0.504}
$$

尿素水溶液の場合

$M=0.0099 \times C_{m}^{0.182}$

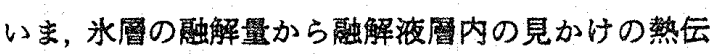
達率 $\alpha$ を定菱すると

$$
\alpha=\frac{L \rho}{T_{1}-T_{2}} \frac{d S}{d t}
$$

と表せる. 次に式(1)と式(4)からヌセルト数 $N_{u}$ と 融解量 $M$ の関係が

$$
N_{u}=\frac{\alpha Y}{\lambda}=M \frac{L}{\lambda}
$$

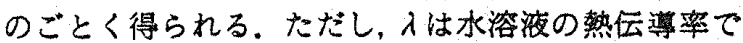
あり，一般に荟度と温度によって変化する.いま，この 熱伝尃率が既知であるならば式 (2)および式 (3)中の $M$ は式(5)を用いることにより直接ヌセルト数に㤎 換することができる。㴤度 $20 \mathrm{wt} \%$ ，温度 $20^{\circ} \mathrm{C}$ の塩化 カルシウムの熱伝導率 ${ }^{(10)}$ は $\lambda=0.576 \mathrm{~W} /(\mathrm{m} \cdot \mathrm{K})$ であ るから, 平均瀆度 $20 \mathrm{wt} \%$ の塩化カルシウム水溶液に よる融解に対しヌセルト数は 6 程度の值をもつことに なる。これは伝導伝熱による触解量の約 6 倍もの融解 量が水溶液を加熱することによって得られることを示 すことにもなることがわかる。

最近, Sammakia ら ${ }^{(4)}$ は壏水中におかれた垂直水板 の融解量から算定したヌセルト数は渡度 $30 \mathrm{wt} \%$, 周

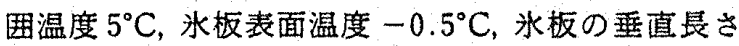
$23.2 \mathrm{~cm}$ の条件て $N_{u}=115$ なる大きな值となるとの 実験結果を報告している。いま，これと同じ温度条件 で純水中の垂直平板の自然対流のヌセルト数(11)を推 定してみると $N_{u}=52$ となる。これらヌセルト数の比 2.2 は，塩水中の垂值水板は自然対流に上る曧解の約 2.2 倍もの融解量が得られることを示している，本研 究で用いた塩化カルシウム水溶溜の凝固点は塩水のそ れよりも低いので, 塩化カルシウム水溶液中の垂直水 板の融解の埸合を想定すると，この場合のヌセルト数 の比は 2.2 よりもさらに大きな值を示すことが予測て きる。

このように融解量が增すのは，跧度の增加に伴う固 液界面温度の低下に起因する気液界面温度の低下によ って,ここでの蒸発量が減少して伝熟望が增すことも
考えられるが，主たる原因は湌度拉散を伴う自発的な 曧解であると考えられ，低凝固点水溶液を加熱して氷

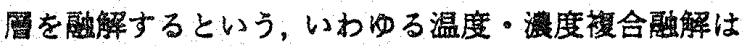
氷症のみならず雪展をも迅速に融解させるに有効な方 法として十分利用し得るものであると思われる。

$$
\text { 4. えと } \hbar^{\circ}
$$

本報は塩化カルシウム水溶液や尿䇣水溶液を加熱し た状態で水平水圈を上から監解させた場合の結果をの ベたものであって，要約すれば次のようになる。

（1）固液界面温度は水溶液の種類や盘度はもとよ り，加熱条件すなわち液相や固相の温度場によっても 変化し,このような融解挙動は従来のNeumann 問題 の場合よりもかなり褔熦な問題であることがわかっ t.

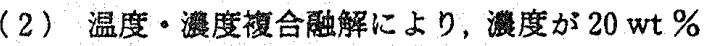
の場合は，純水による融解と比較して尿素水溶液で約 2 倍, 壏化カルシウム水溶液で約 6 倍のごとく、格段 と融解量が增加することがわかった。

（3）融解雷内の算位温度こう配あたりの融解量 $M$ と平均灌度 $C_{m}$ の関係式を求めた。この関係は直接 的に, ヌセルト数 $N_{u} と C_{m}$ との関係に変換できるこ とが珰められた。

終わりに，本研究を遂行するにあたり有益なるご意 見をいただいた北海道大学工学部・関信弘教授に感謝 の意を衰したい。

\section{文南}

（1）日本建設機栈化協会鼣，新防雪工学ハンドブック，(昭 53)，355，棌北出版.

(2) Griffin O.M. Trans. ASME Ser. C, 95-3 (1973), 317.

(3) Rubinstein, L. I., The Stefan Problem, 27 (1971). 19. American Mathematical Society.

(4) Sammakia, B. and Gebhart, B., Int. J. Heat Mass Transfer, 26-10 (1983), 1439.

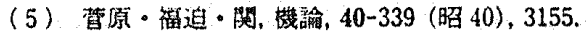

(6) Seki, N., Sugawara, M, and Fukusako, S., Warme.und Stoffubertragung, 11 (1978), 208.

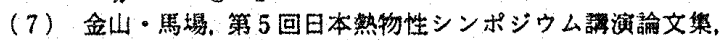
(昭 59-10), 160.

（8）上野，キレート滴定法（昭 47)，南江堂.

（9）厷田，化学反応の速度，(昭54)，46，束京化学同人.

（10）日本機械学会編，流体の熟物性檤雀，(昭 59)，461，日本機 栈学会.

（11）日本機栈学会編，伝熱工学宛料（改湆第 2 版)，(昭 41)，19， 日本嘰械学会. 